\title{
PENERAPAN BUDAYA MAPALUS DALAM PENYELENGGARAAN PEMERINTAHAN DI KABUPATEN MINAHASA PROVINSI SULAWESI UTARA
}

\author{
Rahman Mulyawan \\ e-mail: rahmanmulyawanyahoo.com
}

\begin{abstract}
ABSTRAK
UU Nomor 23 Tahun 2014 tentang Pemerintahan Daerah membuka ruang bagi penyelenggaraan pemerintahan yang sesuai dengan karakteristik daerah masingmasing. Di Kabupaten Minahasa, pemerintahan Daerah memiliki ciri khas dalam penyelenggaraan pemerint ahan yang masih dipegang teguh, yakni Budaya Mapalus. Budaya Mapalus ini memfokuskan kepada kegiatan kerjasama dalam kehidupan bermasyarakat yang secara langsung sangat menjunjung tinggi harmonisasi dalam kehidupan bermasyarakat.

Penelitian ini berupaya menjawab pertanyaan bagaimana penerapan Budaya Mapalus dalam penyelenggaraan pemerintahan di Kabupaten Minahasa. Tujuan penelitian ini untuk memberikan konstribusi bagi pengembangan konsep budaya mapalus melalui proses kaji ulang teori yang telah ada serta penelitian empirik sebagai calon teori. Penelitian ini pun bertujuan menemukan perspektif baru tentang bagaimana hubungan budaya mapalus dengan penyelenggaraan pemerintahan dan otonomi daerah.

Hasil penelitian menunjukkan bahwa penyelenggaraan pemerintahan di Kabupaten Minahasa berjalan dengan penuh keharmonisan dan anti konflik. Tuntutan masyarakat selalu disampaikan secara baik dan diterima secara baik pula oleh Pemerintah Daerah. Demikian pula setiap kebijakan pemerintah selalu disosialisasikan dan diterima secara terbuka oleh masyarakat.
\end{abstract}

Kata Kunci: pemerintah, budaya mapalus, partisipasi, otonomi, masyarakat.

\section{ABSTRACT}

UU 23 Tahun 2014 about Local Governance opens up space for the conduct of the Local Government in accordance with the characteristics of each. In the District of Minahasa has a characteristic in organizing government that still held firm, 
name is Mapalus Culture. This Culture focus to the activities of cooperation in social life that directly very high regard harmonization in the life of society.

This research attempts to answer the question of how the application of Mapalus Culture in the Organization of the Government in the District of Minahasa. The purpose of this research is to provide a contribution to the development of the concept of culture through a process of phased mapalus the theory that there has been empirical research as well as potential theory. This research aims to find a new perspective on how the relationship with the Government organizing Mapalus Cultural and local autonomy.

The results showed that the Organization of the Government in the District of Minahasa runs with full harmony and conflict. The demands of society are always delivered in good and well received by local governments. Similarly, any Government policy always socialized and openly accepted by the community.

Keywords: Government, mapalus culture, participation, autonomy, community.

\section{PENDAHULUAN}

Guna mengantisipasi terjadinya hal-hal yang berpotensi mengganggu hubungan antara pemerintah pusat dan pemerintah daerah serta berindikasi akan memperlemah integrasi nasional, saat ini penyelenggaraan otonomi daerah mulai mengembangkan model pemerintahanyangberbasismasyarakat yang bertujuan selain untuk meningkatkan kualitas integrasi nasional juga untuk melibatkan warga negara secara aktif dalam berbagai bentuk penyelenggaraan kegiatan pemerintahan agar mereka mengetahui serta memahami apa yang menjadi hak dan kewajibannya dalam kegiatan pemerintahan sehingga mereka semakin cerdas dan kritis terhadap berbagai kebijakan yang dikeluarkan oleh pemerintah. Model pemerintahan yang melibatkan warga negara ini oleh peneliti disebut dengan civic governance.

Istilah civic governance merupakan istilah yang masih asing bagi telinga para aparatur negara maupun warga negara Indonesia. Berbagai literatur yang ada lebih banyak memfokuskankepadagoodgovernance atau yang dikenal dengan tata kepemerintahan yang baik dimana banyak menyorot kepada sisi sikap dan perilaku aparat dalam menyelenggarakan wewenangnya sebagai pelayan kepada warga negara. Selain itu terdapat berbagai literatur yang menjelaskan tentang good government atau pemerintahan yang baik dimana lebih menyorot kepada pelaksanaan lembaga atau institusi dalam melaksanakan tugas pokok dan fungsinya.

Berkaitan dengan penyelenggaraan civic governance ini dapat dikatakan 
belum sepenuhnya menyentuh kepentingan serta melibatkan warga negara secara penuh. Dilibatkannya warga negara dalam penyelenggaraan pemerintahan secara langsung diindikasikan akansemakinmeningkatkan kualitas pembangunan karakter bangsa yang sangat menjunjung tinggi kepada rasa memiliki terhadap bangsanya. Civic governance pun secara langsung berindikasi akan meningkatkan sikap nasionalismedanpatriotismedikalangan warga negara.

Dikembangkannya model civic governance yang berkaitan dengan konsep pembangunan partisipatif di Indonesia sehubungan saat ini proses pembangunan masih dilakukan secara konvensional dan bersifat sektoral serta terpusat (dari atas), selain itu, serta kurang mengikutsertakan atau melibatkan potensi yang dimiliki masyarakat (dari bawah). Dalam model civic governance dan konsep pembangunan partisipatif, dicoba mendayagunakan semua potensi yang ada untuk mengembangkan atau menumbuhkanpemecahan-pemecahan secara kreatif dalam pengelolaan pembangunan. Konsep ini mencoba untuk mencari keserasian antara pendekatan pengelolaan dari atas dan dari bawah berdasarkan keterlibatan semua pihak.

Walaupun pemberdayaan masyarakat merupakan kegiatan yang sangat positif, namun di dalam operasionalisasinya peneliti masih menemui berbagai permasalahan atau kendala di lapangan, diantaranya:
1. Pemerintah masih "setengah hati" dalam melaksanakan kebijakan pembangunan partisipatif dan pemberdayaan masyarakat.

2. Masih ditemuinya perbedaan persepsi/pendapat mengenai pemberdayaan masyarakat antara aparat pemerintah dan Lembaga Swadaya Masyarakat/organisasi komunitas.

3. Dalam kegiatan musrenbang, pada umumnya peserta diundang oleh pihak pelaksana/pemerintah. Hal ini dari sisi demokrasi memiliki kelemahan mengingat keabsahan peserta sebagai representasi masyarakat masih diragukan.

4. Forum musrenbang atau sejenisnya seringkali bersifat formalitas.

5. Sumber Daya Manusia aparat pemerintah di tingkat Kelurahan, Kecamatan, dan Kabupaten pada umumnya masih memiliki kelemahan dalam penyusunan program kerja berbasis partisipatif.

Secara umum, permasalahan di tingkat Kabupaten/Kota, Provinsi, ataupun Pusat jauh lebih pelik dan kompleks. Permasalahan tersebut dapat dilihat pada aspek-aspek sebagai berikut:

1. Hubungan perencanaan daerah dengan prioritas pembangunan di tingkat provinsi maupun pusat/nasional cenderung kurang berkaitan satu sama lain.

2. Terdapat dualisme dalam proses perencanaan dan penganggaran 
pembangunan, karena struktur pemerintahan memunculkan dua lembaga yang berbeda antara perencanaan (Bapeda) dan penganggaran (Panggar Eksekutif) yang dikoordinatori oleh Bagian Penyusunan Program atau Bagian Keuangan.

3. Seringkali panitia anggaran eksekutif ataupun legislatif tidak merujuk pada dokumen dan kebijaksanaan perencanaan dan penganggaran yang telah diproses sebelumnya melalui perencanaan partisipatif.

4. Banyak sektortidak berpartisipasi dalam forum-forum perencanaan di tingkat daerah.

5. Informasi, monitoring, dan evaluasi di tingkat komunitas tidak berjalan (tidak ada instrumen dan kemauan politik untuk menjalankan ini), dll.

Guna mengatasi berbagai permasalahan di atas, saat ini terdapat beberapa pemerintah daerah yang mulai mengembangkan konsep civic governance. Salah satu pemerintah daerah yang mulai mengembangkan model civic governance ini adalah Pemerintah Kabupaten Minahasa Provinsi Sulawesi Utara.

Model ini dikembangkan sehubungan di kalangan masyarakat Kabupaten Minahasa sudah lama tertanam rasa kebersamaan yang sangat tebal, senasib, dan sepenanggungan yang diwujudkan dalam gerak operasionalnya melalui
Budaya Mapalus yang memiliki hakekat tentang kebersamaan. Secara umum, budaya mapalus ini sebagai pelaksanaan kegiatan pembangunan yang didorong keinginan untuk memenuhi kebutuhan bersama dengan cara dikerjakan bersama penuh pengertian dan serasi dijiwai semangat untuk memelihara karena disadari semua itu hasil kerja bersama. Sikap kebersamaan masyarakat tersebut sungguh sejalan dengan maksud dilaksanakannya civic governance.

Untuk menambah rasa kebersamaan sesuai dengan amanat budaya mapalus tersebut, perlu dikobarkan lagi dengan semangat harmonisasi/anti-konflik dalam pelaksanaannya dengan model pengembangan civic governance. Dengan model ini, pelaksanaan pemerintahan dapat berhasil optimal karena memadukan aspek edukatif, aspek administrasi pembangunan, aspek pembinaan masyarakat (SDM), aspek pembangunan perekonomian daerah, dan aspek pengolahan sumber daya alam dapat tertata dengan lebih baik.

Di lain pihak, budaya mapalus yang mencerminkan model civic governance dimaksudkan untuk mengingatkan semua lapisan masyarakat Kabupaten Minahasa bahwa sejak dulu memiliki kebersamaan dalam membangun yang harus dipelihara dan ditingkatkan, baik pada hari ini maupun untuk masa yang akan datang. Manusia dan masyarakat boleh berganti karena adanya 
regenerasi, tetapi hendaknya tetap mempunyai rasa kebersamaan. Dengan demikian masyarakat mampu memenuhi kebutuhannya sendiri, yang diawali denganmusyawarah, kemudian diwujudkan. Dan setelah terwujud, dipelihara dengan semangat kebersamaan yang pada akhirnya akan semakin meningkatkan kualitas nasionalisme serta mendukung integrasi nasional sebagai bagian dari tujuan yangharus dicapai dalampembangunan karakter bangsa.

Pemerintah Kabupaten Minahasa melalui kegiatannya berusaha untuk melibatkan masyarakat walaupun belum menghasilkan kualitas yang diharapkan serta dirasakan hasilnya oleh masyarakat itu sendiri. Untuk itulah penelitian ini mengkaji secara mendalam tentang implementasi penerapan budaya mapalus dalam penyelenggaraan pemerintahan di Kabupaten Minahasa.

\section{METODE PENELITIAN}

Pelaksanaan penelitian ini menggunakan desain kualitatif dengan metode studi eksploratif untuk menggali serta menjelaskan sifat dan kondisi suatu subyek dalam keadaan apa adanya. Pemilihan dan penggunaan desain ini terkait dengan tujuan penelitian, yaitu untuk mengeksplorasi dan menganalisis bagaimana budaya mapalus dalam memperkuat civic governance melalui partisipasi masyarakat dalam proses penye- lenggaraan pemerintahan serta mengembangkan model konseptual baru dari budaya mapalus. Melalui desain penelitian ini, selain menggunakan studi pustaka juga mengharuskan peneliti melakukan wawancara dengan melihat dan mendengar informan berbicara yang sebenarnya tentang keadaan dan dirinya sesuai dengan perspektif masing-masing serta mengamati perilaku informan seadanya terhadap lingkungan sesuai dengan posisi dan peran masing-masing. Guna memperoleh informasi dan data yang mendalam tentang fokus penelitian, maka peneliti dibantu dengan penyebaran angket kepada informan sehingga dapat dilakukan eksplorasi dan analisis untuk selanjutnya ditarik kesimpulan.

\section{PEMBAHASAN}

Penelitian tentang penerapan budaya mapalus dalam penyelenggaraan pemerintahan melalui penguatan civic governance dalam kerangka otonomi daerah sebagai landasan memperkokoh integrasi nasional yang juga mengkaji tentang transformasi nilai-nilai pembangunan karakter bangsa serta kerangka model civic governance ini diperkokoh dengan berlandaskan pada peraturan perundang-undangan yang berlaku dan memperhatikan pertimbangan-pertimbangan urusan dan kewenangan pemerintah yang dimiliki oleh daerah otonom, karakteristik, potensi dan kebutuhan daerah, 
kemampuan keuangan daerah, serta ketersediaan sumber daya aparaturnya.

Secara kultural, karakteristik masyarakat Kabupaten Minahasa sangat beragam meski secara umum sering disebut sebagai masyarakat Minahasa. Seiring dengan perkembangan zaman, keanekaragaman masyarakat Kabupaten Minahasa semakin bertambah, tidak hanya dari dimensi kultural namun juga dimensi identitas (ras, etnisitas, agama). Dalam kondisi seperti inilah konsep multikulturalisme memperoleh relevansinya. Wacana multikulturalisme menjadi relevan manakala berhadapan dengan realitas kehidupan sosial di Kabupaten Minahasa yang semakin hari semakin kosmopolis. Kabupaten Minahasa tidak sekedar menjadi milik etnik Minahasa semata, tetapi juga menjadi tanah tempat bermukim dan berkarya berbagai etnik bahkan bangsa.

Sementara secara politik, karakter budaya politik Minahasa cenderung menempatkan elit secara dominan dalam pengambilan keputusan, sementara karakter masyarakat Minahasa kendati menunjukkan diri sebagai masyarakat yang egaliter (sederajat), namun secara kultural masyarakat Minahasa cenderung menunjukkan partisipasi politik yang individualistis. Kondisiinimemberikan peluang kepada pemegang otoritas politik untuk tidak memedulikan kepentingan politik mayoritas masyarakat. Dalam batas tertentu, masyarakat Minahasa memang memperlihatkan ciri egaliter tetapi dalam egaliterisme ini justru muncul sifat-sifat individualistis dalam persoalan yang menyangkut kepentingan pribadi. Dalam kondisi demikian, apatismeatauketidakacuhan politik kerap tampak kepermukaan. Kondisi ini semakin memperlebar peluang pemegang otoritas politik untuk mengesampingkan aspirasi dan kepentingan masyarakat. Perilaku politikmereka akhirnyajugabercirikan individualistis sebab tidak ada pressure signifikan secara kolektif dari masyarakat ketikakepentingan mereka tidak terakomodasi sepenuhnya.

Hal tersebut di atas menunjukkan bahwa masyarakat Minahasa di Kabupaten Minahasa walaupun aktif dan partisipatif dalam proses penyelenggaraan pemerintahan, namun sangat bertahap (tidak terlalu cepat) dalam memahami dan melaksanakan nilai-nilai budaya mapalus yang bernuansa kerjasama dan persatuan. Mereka terindikasi lebih menyukai sifat individualistis ketimbang kolektivitas. Tidaklah aneh dalam transformasi dorongan, motif, dan spirit otonomi daerah yang bernuansa integrasi bangsa di Kabupaten Minahasa akselerasinya tidak secepat seperti daerah lainnya (misalnya daerah yang ada di Kota Manado atau Gorontalo) yang sangat kuat ikat an etnisit asnya sehingga cepat pula akselerasi pembangunan di daerahnya. Terjadinya hal tersebut 
patut diduga adanya permasalahan dalam memahami nilai-nilai persatuan bangsa.

Dalam konteks yang berbeda, masyarakat Kabupaten Minahasa ditandai juga oleh fragmentasi sosialekonomi yang berpotensi memicu konflik horisontal. Setting ekonomi turut menjadi penyebab munculnya kesenjangan sosial yang seringkali berhimpitan dengan identitas etnisitas. Isu-isu mengenai hubungan antara migran dengan penduduk asli dan isu kepemilikan sumberdaya di daerah oleh etnik tertentu, misalnya menjadi salahsatu sumber konfik laten dalam pengelolaan otonomi daerah.

Dalam kondisi kontemporer inilah, transformasi gagasan multikulturalisme dimunculkan sebagai alternatif dalam mengelola keberagaman, sehingga keberagaman dapat menjadi aset yang menunjang pengelolaan otonomi daerah. Secara konkret, pengadopsian multikulturalisme tercermin dalam substansi setiap kebijakan publik yang dibuat oleh DPRD bersama dengan Pemerintah Daerah.

Langkah transformasi pertama yang telah dilakukan untuk menumbuhkan budaya politik multikulturalisme di Kabupaten Minahasa adalah menemukan kembali nilai-nilai lokal, kemudian menginventarisasi permasalahan yang selama ini dihadapi oleh masyarakat Kabupaten Minahasa di bidang politik, pemerintahan, hukum, sosial, budaya, dan sebagainya untuk selanjutnya mencoba menerapkan nilai-nilai budayatersebut untuk mencari alternatif penanganan masalah tersebut. Menciptakan sebuah tempat bagi beragam manusia dari etnis berbeda-beda namun tetap diikat oleh nilai-nilai ke-Minahasa-an sebagai dasar perilakunya. Untuk mengintegrasikan nilai-nilai budaya Minahasa tadi, diperlukan suatu strategi budaya yang bukan hanya untuk merevitalisasi nilai-nilai budaya Minahasa tetapi juga mengarahkan revitalisasitersebut untukmewujudkan Kabupaten Minahasa yang multikultural dengan masyarakat yang menjunjung tinggi persatuan dan kesatuan guna kepentingan integrasi bangsa. Komitmen untuk mengakui keragaman sebagai salah satu ciri masyarakat Kabupaten Minahasa dewasa ini tidaklah berarti terjadinya ketercabutan dari akar budaya lokal (Minahasa) karena pada saat yang sama sesungguhnya juga terdapat simbol-simbol, nilai-nilai, strukturstruktur, dan lembaga-lembaga dalam kehidupan bersama yang mengikat berbagai keragaman tersebut. Dalam karakter masyarakat yang mengarah pada kosmopolitanisme, multikulturalisme menjadikan pola interaksi dan identifikasi diri menjadi bersifat multi sehingga seseorang tidak hanya merasa diri sebagai orang Minahasa karena dia dilahirkan dari orang tua beretnis Minahasa, tapi lebih dari itu, seseorang yang bukan etnis Minahasa tapi lahir di Minahasa pun merasa 
dirinya sebagai bagian dari masyarakat Minahasa.

Kondisi masyarakat Kabupaten Minahasa yang multikulturalisme dapat dimanfaatkan sebagai faktor pendorong bagi munculnya kreativitas dan inovasi yang pada gilirannya akan mendukung percepatan pencapaian spirit otonomi daerah yang bertujuan memperkokoh pengelolaan pemerintahan yang partisipatif dalam rangka mewujudkan integrasi nasional.

Sesungguhnyapadamasasekarang terdapat beberapa nilai atau norma yang berkembang di masyarakat Minahasa yang mungkin dapat dikategorikan sebagai pandangan mereka terhadap masalah politik dan pemerintahan. Nilai-nilai budaya lokal banyak mengandung muatan moralitas meskitidakdinyatakansecaraeksplisit. Moralitas tersebut tidak hanya tergambar dari relasi sosial antarmanusia, antarelit, dan antarmassa, tapijugaantaramanusiadanlingkungan alamnya. Nilai-nilai yang menjadi acuan moral tersebut dapat berbentuk semboyan, nasehat, atau peribahasa yang berkembang dari mulut ke mulut, sehingga baik secara langsung maupun tidak langsung dijadikan semacam pedoman atau ukuran dalam menilai suatu tindakan atau perbuatan masyarakat maupun elit penguasa.

Kesederhanaan konsep kepemimpinan dan figur pemimpin dalam nilainilai adat Minahasa bersumber dari pandangan hidup orang Minahasa yangberusahamengambiljalan tengah, yang diartikan sebagai tingkah laku atau tindakan yang seimbang dan berkecukupan, tidak kekurangan atau tidak berlebihan. Pandangan ini bisa mengandung aspek positif sekaligus aspek negatif. Positifnya, pandangan hidup ini menyebabkan orang Minahasa tidak menonjolkan diri tetapi, negatifnya, sikap seperti ini dapat diartikan sebagai orang yang tidak berani mengambil resiko dalam mempertahankan sesuatu.

Permasalahanaktualyangmenjadi bahan diskusi di kalangan tokoh-tokoh masyarakat, baik dari kalangan budayawan, agamawan, akademisi, bahkan politisi adalah munculnya kekhawatiran di kalangan masyarakat bahwa orang Minahasa suatu ketika mungkin akan kehilangan identitas keMinahasa-annya, yang terpinggirkan di tengah pesatnya pembangunan. Kekhawatiran ini timbul karena secara kultural, etnis Minahasa berlatarbelakang budaya masyarakat peladang sehingga sulit bersatu, tidak memiliki ikatan kekeluargaan yang kuat, dan memiliki prinsip yang cenderung selalu mengalah. Ini semua berlaku pula di masyarakat Kabupaten Minahasa.

Sementara itu, figur pemimpin formal yang diharapkan dapat menampilkan nilai-nilai Minahasa dalam pola kepemimpinan ternyata tidak mampu mempertahankan legitimasinya di mata masyarakat. Menurunnya kepercayaan masyarakat pada figur pemimpin ini tersirat dari sinyalemen 
bahwa Minahasa dirusak bukan hanya oleh pendatang tapi juga oleh kebijakan pemerintah setempat.

Hubungan antara masyarakat dan figur-figurpimpinan formalmengalami perubahan. Sebagai tingkat tertinggi dalam jabatan eksekutif di daerah, kepemimpinan kepala daerah menjadi figur yang diharapkan mampu mempersatukan warganya dan meredam timbulnya konflik. Akan tetapi, dalam banyak kasus, kepemimpinan kepala daerah dan juga elit-elit politik lainnya di Parpol atau DPRD justru menerapkan pendekatan konflik dalam melaksanakan sejumlah kebijakannya ataujustrumemunculkan perilaku yang tidak pantas diteladani dalam kaitannya dengan etika politik.

Pola kepemimpinan dari figur pemimpin formal yang berasal dari Minahasa ternyata dirasakan telah mampu menampilkan nilai-nilai kepemimpinan Minahasayang bercirikan baik dalam perilaku yang ramah, memakai aturan, baik budi bahasa,sikap maupuntingkah laku. Secara tidak langsung krisis kepemimpinan lokal ini turut mempengaruhi pergeseran figur ideal pemimpin formal yang diharapkan masyarakat.

Berkaitan dengan uraian di atas dapat diketahui bahwa peran serta masyarakat dalam proses penyelenggaraan pemerintahan lebih banyak dilakukan berdasarkan budayamapalus secara kolektivitas, sehingga transformasi spirit otonomi daerah yang partisipatifpun dilakukan melalui pembangunan multikultural yang mengadopsi nilai-nilai kepemimpinan Minahasa.

Dalam penyelenggaraan pemerintahan, tidak dapat dipungkiri bahwa dalam beberapa hal seluruh warga masyarakat tidak mungkin dilibatkan dalam membuat kebijakan, tetapi bagaimanapun dalam membuat kebijakan yang sifatnya untuk kepentingan publik sudah seharusnya pemerintah melibatkan warga masyarakat yang disebabkan oleh ikatan mapalus. Jika tidak, suatu gejolak sosial akan terjadi terhadap kebijakan yang dibuat oleh pemerintah itu sendiri. Banyak contoh produk kebijakan yang sangat kontra di masyarakat sebagai akibat pemerintah senantiasa tidak membuka diri untuk melibatkan masyarakat dalam membuat kebijakan. Pemberdayaan partisipasi masyarakat sipil at au civil society yang berbasis budaya mapalus merupakan alat ampuh dalam menentukan arah dan kebijakan pembangunan pada masa-masa mendatang. Keterlibatan ini akan memberikan dampak yang positif terhadap keputusan dan kebijakan yang diambil atau yang akan diimplementasikan, karena dapat membangun sinergi antara pemerintah dan masyarakat itu sendiri.

Partisipasi masyarakat dalam membuat kebijakandapat digambarkan dengan 'tangga partisipasi', dalam hal ini rakyat diposisikan sebagai anak tangga terbawah yang senantiasa 
mengetahui masalah sosial yang sesungguhnya. Tanpa memberdayakan dan konsultasidi anaktanggaterbawah, pemerintah tidak akan pernah tahu apa yang sesungguhnya yang dibutuhkan oleh rakyat. Apabila komunikasi di tingkat bawah telah diperkuat maka akan terjadi dialog antara pemerintah dan masyarakat. Dengan demikian, pemerintah akan lebih efektif dan efisien dalam membuat kebijakan.

Dalam Surat Edaran Bersama Menteri Dalam Negeri dan Menteri Negara Perencanaaan Pembangunan Nasional/Ketua Bappenas nomor 0259/M.PPN/I/2005 dan 050/166/SJ, dijelaskan bahwa proses pembuatan kebijakan pembangunan bersifat elitis, artinya pemerintahlah yang menjadi penentu kebijakan pembangunan, sedangkan masyarakat berperan memberikan masukan kepada pemerintah tentang apa yang dibutuhkan oleh masyarakat. Apabila model ini diadopsi dalam upaya implementasi partisipasi masyarakat dalam pengambilan keputusan, maka yang diperlukan adalah keterbukaan pemerintahuntukmenjadikanmasukan masyarakat sebagai dasar dalam menyusun kebijakan publik. Selama ini permasalahan yang ditemukan adalah bukan karena kualitas dan kuantitaspartisipasimasyarakatrendah tetapi justru terletak pada praktekpraktek pemerintah yang mengabaikan usulan masyarakat. Berkaitan dengan inidapat diketahuibahwapermasalahan kita bukan pada rendahnya kualitas dan kuantitas tingkat partisipasi masyarakat, tetapi terletak pada keterbatasan mekanisme politik bagi keterlibatan warga negara dalam menuntut akuntabilitas dan keterbukaan. Hambatan utama dalam mengupayakan pemerintah yang terbuka dan akuntabel justru terletak pada institusi-institusi yang cenderung memiliki kepentingan sendiri yang berbeda dengan kepentingan publik dan praktek pemerintahan yang tidak peka terhadap desakan kepentingan publik. Kondisi ini dapat mendorong praktek terjadinya korupsi dalam sebuah mekanisme yang saling melindungi dan sampai saat ini tidak dapat disentuh oleh tuntutan keterbukaan dan akuntabilitas.

Melalui musyawarah perencanaan pembangunan, apa yang diilustrasikan oleh peneliti tentang "tangga partisipasi” sebenarnya sudah dilaksanakan di Indonesia, namun dalam pelaksanaan dilapangan banyak dihadapi berbagai permasalahan. Selain permasalahan yang berasal dari instirusi dan praktek-praktek pemerintah, pemasalahan yang dihadapi pemerintah untuk melibatkan masyarakat dalam kebijakan pembangunan adalah: pertama, meskipun semua perangkat hukum memberikan ruang terhadap partisipasi publik, tetapi semua perangkat hukum tersebut tidakmengat ursecaraeksplisit bagaimana, dimana, dan siapa yang dilibatkan dalam pengambilan keputusan publik. Kedua, banyak lembaga swadaya masyarakat (LSM) dan organisasi kemasyarakatan 
(Ormas) yang bergerak di berbagai bidang namun memiliki keterbatasan dalam membawa aspirasi rakyat, sehingga tidak terbent uk sinergi antara rakyat dan pemerintah. Ketiga, banyaknya Ormas dan LSM di era reformasi menyulitkan untuk menentukan Ormas mana yang dapat dianggapmewakiliaspirasimasyarakat. Pengalaman selama ini banyak kebijakanpartisipasiyangdilaksanakan oleh pemerintah diprotes oleh masyarakat, karena wakil masyarakat tersebut dianggap tidak mewakili masyarakat.

Di era reformasi, Ormas dan LSM di Kabupaten Minahasa berkembang sangat banyak dan satu dengan lainnya bersifat independen meskipun bergerak dalam bidang yang sama. Misalnya banyak Ormas dan LSM yang bergerak di bidang lingkungan hidup, tetapi satu dengan lainnya berbeda visi dan misinya. Hal seperti ini tidak mengunt ungkan bagi Ormas it u sendiri dalam menyampaikan usulannya kepada pemerintah. Namun dilain pihak, pemerintah sebagai pemegang inisiatif perencanaan sulit untuk memilih organisasi mana yang akan dilibatkan dalam proses perencanaan.

Dari hasil penelitian dan wawancaradenganberbagairesponden, secara garis besar dapat diketahui beberapa program kegiatan yang berbasis penerapan budaya mapalus dantelahdilaksanakanoleh pemerintah Kabupaten Minahasa, diantaranya adalah: (a) Mengembangkan wilayah kecamatan sebagai pusat pelayanan pemerintahan dengan konsep pelimpahan sebagian kewenangan dari Bupati kepada Camat yang harus disertai dengan personil, peralatan, dan pembiayaan; (b) Menjadikan Camat sebagai manajer Kecamatan berdasarkan karakteristik wilayah dan memberikan pelimpahan kewenangan secara penuh dalam konteks menghadapi masalah-masalah di kecamatan khususnya dibidang kebersihan, ketertiban, dan keamanan yang merupakan kebutuhan utama masyarakat; (c) Melakukan evaluasi pelayanan pemerintahan untuk mengetahui tingkat indeks kepuasan masyarakat terhadap pelayanan yang diberikan oleh pemerintah kepada masyarakat; (d) Melakukan evaluasi penataan organisasi di pemerintah Kabupaten Minahasa sebagai konsekwensi adanya Peraturan Pemerintah (PP) yang mengatur tentang kewenangan dan PP yang mengatur Penataan Organisasi; (e) Melakukan evaluasi anggaran, evaluasi personil, dan mekanisme kerja setiap desa/kelurahan dan Kecamatan dengan penerapan evaluasi beban kerja dan Kepmendagri Nomor 158 tahun 2004 karena dengan adanya pengukuran beban kerja antardaerah maka antara daerah yang memiliki beban kerja yang lebih berat tidak berarti menerima dana yang sama dengan daerah yang memiliki beban kerja yang biasa; (f) Melakukan penataan desa/kelurahan dan kecamatan dengan harapan pemerintahKabupaten Minahasadapat 
mewujudkan konsep close to custumer (mendekatkan pelayanan kepada pelanggan/masyarakat); (g) Menjadikan desa/kelurahan sebagai klinik pemerintahan dengan harapan bahwa kinerja pemerintah Kabupaten Minahasa akan dibangun dengan baik dan simultan dimulai dari tingkat desa/ kelurahan, dengan harapan pemerintah Kabupaten Minahasa dapat memilih beberapa desa/kelurahan yang menjadi desa/kelurahan percontohan; (h) Mengembangkan konsep pembangunan di tingkat komunitas masyarakat terendah (RT) dengan melanjutkan program jejaring asmara dalam rangka mengcover tingkat urgensitas kebutuhan masyarakat; (i) Menata kembali pelayanan pemerintahan diwilayah perbatasan daerahyang pada umumnyamerupakan kawasan tertinggal; (j) Melakukan evaluasi terhadap rencana strategis dari semua satuan kerja perangkat daerah di lingkungan pemerintah Kabupaten Minahasa dengan harapan setiap Satuan Kerja Perangkat Daerah (SKPD) memiliki konsep one vision one product; (k) Melakukan uji kompetensi untuk setiap penempatan pejabat struktural di lingkungan Kabupaten Minahasa; (1) Melakukan program studi banding bagi eksekutif maupun legislatifdalam meningkatkan kapasitas pemerintahan; (m) Meningkatkan pelaksanaan penegakan hukum yang berkeadilan, khususnya pemberantasan KKN di Kabupaten Minahasa;serta (n) Meningkatkan kualitas aparaturpemerintahKabupaten
Minahasa dengan memberikan kesempatan kepada seluruh aparat pemerintahan dalam melanjutkan pendidikan dan mengikuti workshop atau pelatihan baik struktural maupun fungsional.

\section{SIMPULAN DAN SARAN}

Pada dasarnya karakteristik masyarakat Kabupaten Minahasa yang religius, kritis, kreatif, tanggap, dan konstruktif merupakan potensi yang dapat dikembangkan ke arah penerapan budaya mapalus dalam penyelenggaraan pemerintahan melalui rasionalisasi dan modernisasi. Semangat kegotongroyongan merupakan potensi dalam pelaksanaan partisipasi dalam pembangunan yang dilestarikan dan ditingkatkan ke arah yang lebih positif menuju penerapan budaya mapalus itu sendiri.

Agar budaya mapalus tetap lestari di alam Minahasa, maka sudah seharusnya penyelenggaraan pemerintahan senantiasa berlandaskan kepada nilai-nilai yang terkandung dalam budaya mapalus.

\section{DAFTAR PUSTAKA}

Dwiyanto, Agus. 2002. Reformasi Birokrasi Warga Negara di Indonesia. Jogjakarta: Pusat Studi Kependudukan dan Kebijakan Universitas Gajah Mada. 
El Mubarok, Zaim. 2009. Membumikan Pendidikan Nilai. Bandung: Alfabetha.

Frederickson. 1984. Pemberdayaan dan Partisipasi Masyarakat (terjemahan). Yogyakarta: Akademia.
Garna, Yudhistira K. 1999. Metode Penelitian: Pendekatan Kualitatif. Bandung: Primaco Akademika.

Grant. 1979. Partisipasi Masyarakat dalam Pembangunan. Jakarta: Djambatan 